IZA DP No. 9410

Temporary Employment, Demand Volatility and Unions: Firm-Level Evidence

Francesco Devicienti

Paolo Naticchioni

Andrea Ricci

October 2015 


\title{
Temporary Employment, Demand Volatility and Unions: Firm-Level Evidence
}

\author{
Francesco Devicienti \\ University of Torino, Collegio Carlo Alberto \\ and IZA
}

Paolo Naticchioni

University of Roma Tre

and IZA

\section{Andrea Ricci}

ISFOL

\section{Discussion Paper No. 9410 \\ October 2015}

\author{
IZA \\ P.O. Box 7240 \\ 53072 Bonn \\ Germany \\ Phone: +49-228-3894-0 \\ Fax: +49-228-3894-180 \\ E-mail: iza@iza.org
}

Any opinions expressed here are those of the author(s) and not those of IZA. Research published in this series may include views on policy, but the institute itself takes no institutional policy positions. The IZA research network is committed to the IZA Guiding Principles of Research Integrity.

The Institute for the Study of Labor (IZA) in Bonn is a local and virtual international research center and a place of communication between science, politics and business. IZA is an independent nonprofit organization supported by Deutsche Post Foundation. The center is associated with the University of Bonn and offers a stimulating research environment through its international network, workshops and conferences, data service, project support, research visits and doctoral program. IZA engages in (i) original and internationally competitive research in all fields of labor economics, (ii) development of policy concepts, and (iii) dissemination of research results and concepts to the interested public.

IZA Discussion Papers often represent preliminary work and are circulated to encourage discussion. Citation of such a paper should account for its provisional character. A revised version may be available directly from the author. 


\section{ABSTRACT \\ Temporary Employment, Demand Volatility and Unions: Firm-Level Evidence*}

This paper investigates the effect of workplace unionization and product market volatility on firms' propensity to use temporary employment. Using Italian firm level data, we show that unionization and volatility have a positive impact on the share of temporary contracts. However, as volatility increases the union effect becomes negative, suggesting that in a highly volatile economic environment unions may be concerned about the weakening of their bargaining power associated with an extensive use of temporary workers. Furthermore, these effects are at work only for the use of non-training temporary contracts, while training temporary contracts are not affected by unions, volatility and their interplay. We argue that this occurs because non-training temporary contracts can be used by firms as a buffer stock to cope with uncertainty and by unions to protect insiders, while training temporary contracts are more likely to be used as a screening device for future permanent positions.

JEL Classification: J51, J23, J24

Keywords: $\quad$ unions, temporary workers, training, product demand volatility, firms

Corresponding author:

Francesco Devicienti

Dipartimento di Scienze Economico-Sociali e Matematico-Statistiche

Università di Torino

Corso Unione Sovietica 218bis

10134 Torino

Italy

E-mail: francesco.devicienti@unito.it

\footnotetext{
* We thank ISFOL for the availability of the RIL data and for having funded the research project. The contents of the paper are the sole responsibility of the authors.
} 


\section{Introduction}

In the last few decades, most European countries have enacted a series of labor market reforms designed to endow firms with enhanced contractual flexibility in the face of the increasing economic uncertainty related to globalization and technological change. These reforms have generally been introduced "at the margin", facilitating the use of temporary contracts for new hires while leaving employment protection for open-ended contracts unaffected. As a result, the diffusion of temporary employment has become one of the distinctive features of the European labor market, ultimately producing dual labor markets where temporary workers might be entrapped in "low quality" jobs (Boeri, 2012). ${ }^{1}$

For this reason, economists and policy makers are showing increasing interest in identifying the determinants of temporary employment. Most of the literature has generally focused on labor supply dynamics, typically using individual data from household and labor force surveys (e.g., Booth et al., 2002). The firms' demand for temporary workers has been studied rather less, despite its considerable importance, as highlighted by the empirical evidence showing that fixed-term contracts are typically favored more by firms than by workers (e.g., Francesconi and GarciaSerrano, 2004).

The institutions and the characteristics of the economic environment in which firms operate clearly constitute important determinants of the demand for temporary employment. While much of the literature has focused on the difference in firing costs between open-end and temporary contracts as a key determinant (Boeri and Garibaldi, 2007), two additional issues have been considered.

The first issue concerns the role of unions, which are of primary relevance in understanding the employment dynamics in European labor markets. An under-explored issue, which lies at the heart of this paper, is whether the pervasive presence of unions and collective bargaining in most

\footnotetext{
1 Temporary contracts account for $14 \%$ of EU employment and for more than $50 \%$ of new hires (OCSE, 2008).
} 
EU countries may have contributed to the diffusion of temporary employment, partly as a way to maximize the utility of the "insider" workers (e.g., permanent and older workers) that the unions mostly represent. One of the insights from the insider-outsider literature is that the unions may be a contributing factor to labor market duality if they reckon that temporary employment acts as a "buffer" to isolate permanent workers from the negative effects of demand uncertainty and technological shocks (Bentolila and Dolado, 1994; Saint Paul, 1996). Moreover, the presence of unions at the workplace may increase the bargaining power of permanent/insider workers on wages, thus inducing firms to make use of fixed term contracts to exploit numerical and wage flexibility (Abraham and Taylor, 1996). However, the unions may also oppose the diffusion of temporary contracts, as temporary workers are typically less unionized and less engaged in industrial relations, representing a potential threat to union strength and representativeness (Heery, 2004; Salvatori, 2012). ${ }^{2}$ To sum up, the presence of trade unions at the workplace has a potentially ambiguous effects on a firm's demand for flexible contracts. Moreover, both direct and indirect influences are at play. On the one hand, unions may directly contribute to a firm's strategy on labor organization and hiring policies. This may happen formally, through firm-level specific agreements with the unions, or more informally, through employee consultation and involvement practices. This mechanism is consistent with the intuition that unions may boost the use of temporary workers to protect insider workers. On the other hand, the presence of a union might also influence a firm's use of temporary workers indirectly, e.g. by inducing firms to increase their share of temporary contracts in order to reduce a union-driven rise in labor costs.

The second factor that has drawn attention in the literature to the determinants of the demand for temporary employment concerns the volatility of the economic environment in which firms operate. Abraham and Taylor (1996) and Bentolila and Saint Paul, (1994), among others, argue that in more volatile environments firms increase the use of temporary employment, which can be

\footnotetext{
2 Unions may also be concerned with an excessive use of fixed-term contracts due to the negative effects on social welfare and labor market cohesion (Visser, 2002).
} 
considered as a valuable buffer stock to adjust to fluctuations. The volatility of the economic environment, however, does not only affect the behavior of the firms: the unions' behavior is also likely to be affected, if they anticipate the need for more frequent negotiations of labor conditions when demand volatility increases (Booth, 1995; Freeman and Medoff, 1984). This issue has been largely neglected by the literature on temporary employment, despite its importance in understanding the role of the unions as a contributing factor to labor market duality.

To the best of our knowledge this is the first paper that focuses explicitly on the interplay between workplace unionization and demand volatility in affecting the propensity to use temporary employment. Another contribution offered by this paper lies in investigating whether the effects of union and demand volatility on the use of temporary employment is heterogeneous across different types of temporary contracts. In particular, we distinguish between fixed-term contracts without any training clauses and temporary contracts where a training clause is expressly introduced by the labor legislation. We expect the two types of contracts to have different roles in fulfilling both the firm's and union's objectives.

We focus our empirical analysis on Italy, an interesting case to study since, on the one hand, there has been a notable increase in temporary contracts in the last few decades and, on the other, the unions have considerable power in bargaining with firms over all aspects of the employment relationship.

We rely on a rich firm-level dataset, the Employer and Employee Survey (RIL), conducted by the Institute for the Development of Workers Professional Training (ISFOL) in 2005 and 2007. The data are representative of firms operating in the Italian extra-agricultural sector, and provide extensive information about temporary contracts, union presence and other workplace characteristics. In particular, the data enable us to study the effect of unionization on the share of the different types of temporary employment, rather than simply on a dummy variable indicating that the firm employs any amount of temporary contracts (e.g., Salvadori, 2009; Gramm and Schnell, 2001). We 
supplement the RIL data with balance-sheet information from the AIDA database by Bureau van Dijk, which contains the universe of incorporated firms in the non-financial private sector. We use AIDA to construct measures of the economic volatility faced by firms and unions based on past sales at the sectoral level, and moreover to obtain firm-level instrumental and control variables for our econometric analyses.

Our preferred econometric specification regresses the share of temporary workers on union status, volatility, and their interaction, after controlling for an ample set of firm and labor force covariates. To account for the potential endogeneity of workplace unionization, we present consistent sets of results based, alternatively, on a cross-sectional IV strategy and a firm fixed-effect strategy.

Our main findings can be summarized as follows. First, both volatility and workplace unionization have a positive impact on the firm's use of temporary contracts. The effect of volatility is consistent with the previous literature showing that volatility encourages firms to employ temporary workers to adjust the labor input more easily. The impact of unions, on the other hand, can be related to the direct and indirect mechanisms mentioned earlier. Unfortunately, our data do not allow us to disentangle the different impacts of the two mechanisms.

Our second result relates to the presence of a significant interaction effect between workplace unionization and demand volatility. In particular, we find that as volatility increases, the union effect becomes negative. This result suggests that in a highly volatile economic environment the unions may oppose intensive use of fixed-term contracts to prevent the weakening of their bargaining power. This is more likely to happen in volatile environments, characterized by high frequency of renegotiation of labor conditions and/or wage setting at the workplace (e.g., Addison 2014).

Our third result is that the effects of unions and volatility are heterogeneous across different types of temporary contracts. The presence of unions per se increases the demand for non-training 
temporary contracts, as does a higher demand volatility, while these effects are never detected in the case of training temporary contracts. The negative interaction effect is also only statistically significant for non-training temporary contracts. We argue that these findings are due to the different nature of the two contractual arrangements. In particular, non-training temporary contracts are typically used by firms, and encouraged by unions, as a buffer stock for insider workers. Training temporary contracts, on the other hand, are more likely to play a screening role for a firm's core-staff needs, and are generally more expensive. Hence, they cannot represent an equally valid buffer both for the firms and for the union's insiders.

Overall, the paper shows that the existing literature might hitherto have overlooked the fact that the effect of the unions on the demand for temporary contracts crucially depends on the type of temporary contracts considered, as well as the interplay between the unions' objective function and the volatility demand conditions faced by the firm.

The paper is organized as follows. In section 2 we review the relevant literature. In Section 3 we provide the institutional setting and in section 4 we describe the data and show the descriptive statistics. We perform the econometric analysis in Sections 5, while in section 6 we take into account the different types of temporary contracts. Section 7 concludes.

\section{The related literature}

Temporary contracts have been widely studied in the last few decades from different standpoints. Attention has been paid mainly to the alleged beneficial impacts in terms of unemployment reduction, especially for young workers (OECD, 2008), as well as the potential negative effects for the welfare of workers (Booth et al., 2002; Blanchard and Landier, 2002; Boeri, 2012) and labor productivity (Battisti and Vallanti, 2013; Cappellari et al., 2012; Damiani et al., 2014).

It is worth noting that the majority of the applied research on this issue is based on individual data that are unlikely to account appropriately for the firms' incentives to hire temporary workers. 
Indeed, the available evidence shows that a substantial share of temporary employment appears to be involuntary on the part of the worker (Booth and Francesconi, 2003). This suggests that firms' characteristics and personnel policies play a key role in determining the diffusion of temporary contracts. For instance, Caggese and Cugnat (2008) make use of firm panel data to show that financially constrained firms use temporary workers more intensively than financially unconstrained firms do.

More in line with our paper, there is a strand of the literature focusing on the impact of unions on the use of temporary employment. The evidence for the US is controversial. For instance, Abraham and Taylor (1996) argue that firms may use fixed-term contracts to counter the increase in labor costs brought about by unions representing the interests of permanent workers. However, Gramm and Schnell (2001), using a small sample of firms from Alabama, find a negative correlation between union coverage and the probability of using temporary employees in the main occupational groups. Houseman (2001) uses a sample of more than 500 US firms and reaches a similar conclusion. Conversely, using aggregate data from the US, Autor (2003) finds that the spread of temporary employment proved faster in states where the unions declined more slowly.

As for Europe, the empirical research specifically investigating the effects of unions on firms' propensity to employ temporary workers is rather scant and provides mixed results. Francesconi and Garcia-Serrano (2004) find no evidence of correlation between the share of temporary employment and unionization, using data on Spanish firms. Salvatori (2012) uses British data and finds no support for the hypothesis that firms under the threat of unionization are more likely to use fixed-term workers, and only weak evidence of negative effects for agency workers.

Of course, industrial relation practices and legislation on the utilization of fixed-term contracts differ markedly across countries, which might partly account for the divergent results. Salvatori (2009) provides the first comparative study by using workplace level data from a number of European countries. In general he reports that unionized workplaces are more likely to use 
temporary contracts across Europe, and hence the unions contribute to creating labor market duality and welfare disparities between insider and outsider workers.

Our paper adds to this literature in two main respects. Departing from the practice in the papers so far published, we investigate whether there are heterogeneous impacts of union and demand volatility across two major categories of temporary contracts, namely those explicitly offering training to the worker and those where a training clause is absent. The difference between these two types of temporary contracts appears crucial for firms' personnel strategies, and has different implications for the employment prospects and the welfare of workers (e.g., Berton et al., 2011).

Another potential caveat of the existing empirical literature is that the impact of unionization on the firms' use of temporary contracts is generally examined without taking into account the role of economic uncertainty. This concern appears to matter for a number of reasons. First, economic fluctuations have long been recognized as an important determinant of a firm's choice to hire on a temporary or permanent basis. For example, Bentolila and Saint Paul (1994) show that the difference in firing costs between permanent and temporary workers in Spain is associated with a higher cyclical elasticity (to sales) of the demand for temporary employment. In other words, firms can use temporary workers as a buffer, dropping them during recessions and allowing for a faster increase of employment during upturns. Boeri and Garibaldi (2007) find that, in the short run, Italian firms' propensity to hire on a temporary basis depends largely on the "states" of economic conditions and business cycle. ${ }^{3}$

Second, including a measure of the firms' demand volatility is important to reduce omitted variable bias when investigating the impact of unionization on the demand for temporary employment. This is because output volatility is likely to be correlated with both the demand for

\footnotetext{
${ }^{3}$ See also Holmlund and Storrie (2002), Costain et al. (2010), and Lotti and Viviano (2011) for related contributions.
} 
temporary employment and workplace unionization if insider workers look to the unions to make their jobs safer.

Third, there are no studies on the interaction effects between the volatility of the economic environment and the presence of unions at the workplace. In particular, product demand volatility is likely to affect the timing and objectives of the bargaining process between unions and firms over wages and employment conditions. Economic uncertainty may therefore constitute a relevant dimension of heterogeneity in the impact of unionization on a firm's demand for temporary employment, hitherto neglected in the literature.

\section{Institutional background}

Italy is characterized by a two-tier bargaining system, with a dominant sectoral tier and a supplementary decentralized tier where bargaining is usually carried out at the company/local level.4 The main objectives of the sectoral agreements (National Collective Labor Agreements, NCLAs) are to protect real wages and to set common economic and normative conditions for sectoral workers nationwide. At the decentralized level, it is possible to negotiate performance and productivity-related wage increases. In addition, the second level bargaining may address a number of additional matters, such as working hours, employment training, labor organization and union relations, in order to gain flexibility for organizational changes and competitiveness. ${ }^{5}$ Application to all workers in the firm of the conditions arrived at through bargaining at the

\footnotetext{
4 A territorial level (mostly at the province level) also exists, but is typically confined to particular industries, e.g., construction and agriculture.

5 There are no official data on the diffusion and content of decentralized bargaining. Survey data suggest that the coverage is at around 60 percent of employees and from 15 to 25 percent of firms (Damiani and Ricci, 2014), with greater incidence in manufacturing and larger firms. A large fraction of second-level agreements (over 60 percent) contain wage increases related to productivity gains, but agreements dealing with workplace organizational changes, performancebased human resource management practices and employment flexibility are not uncommon, and broadly cover the remaining 40 percent of cases.
} 
decentralized level is the standard practice (Cella and Treu, 1999). Second-level bargaining is subject to the limits and provisions defined by the specific NCLAs applied in the productive unit. ${ }^{6}$

Italian law gives the workers the right to join a union, engage in union activity and organize a plant-level union representation structure. The main workplace representation body is the socalled 'unitary workplace union structures' (Rappresentanze Sindacali Unitarie, RSU). The RSU includes features of works councils (e.g., worker representatives are elected by all the employees) but can also be associated with trade union bodies (e.g., worker representatives are usually elected from competing candidates on trade unions lists). Hence, in Italy union and employee representation are entrusted to a single body (single-channel representation), as opposed to a dualchannel system where union delegates operate alongside works councils. ${ }^{7}$ Worker representatives are able to negotiate at the plant level on issues delegated from the industry-wide level, and have rights to information and consultation (e.g., D'Amuri and Giorgiantonio, 2015).

As for temporary contracts, a process of labor market deregulation started in the mid- 1990s (with the "Treu package" in 1997, the Legislative Decree 368 of 2001 and the Law 30 of 2003). Much as has been the case in other European countries, these reforms introduced various types of temporary contracts without changing the legislation on permanent (open-ended) contracts. Of the temporary contracts, fixed-term contracts are the most popular, at around 7 percent of the workforce (against 84 percent of open-end contracts). ${ }^{8}$ Permanent and fixed-term contracts only differ by virtue of a fixed term. Due to the presence of employment protection legislation, fixed term contracts can be rescinded (or 'not renewed') more easily. All other working conditions, such as wages, working times, pension rights, probation period, are identical and firms pay the same

\footnotetext{
${ }^{6}$ Decentralized agreements are only supplementary to, and applicative of, the NCLAs. The possibility of opting-out or derogating from NCLAs was formally introduced only recently, after 2009, beyond the sample period we analyze.

7 There is also an alternative plant-level union body (Rappresentanza Sindacale aziendale, RSA) elected by the members of a particular union. RSUs have tended to replace RSAs, which are usually found in smaller companies and in certain sectors like banking.

8 See Cappellari et al (2012), as reference for these labor contracts shares, and also for those in the following.
} 
social security contribution rates for the two types of contracts. A fixed-term contract can be renewed only once and its cumulated duration cannot exceed three years with the same firm.

Apprenticeship represents another form of temporary contracts, at around 3 percent of the workforce. Firms can use this contract only for young workers (up to 30 years of age), must provide certified training and, in exchange, are granted lower social security contributions. The maximum cumulated duration is three years. ${ }^{9}$

As discussed earlier, the presence of trade unions at the workplace may exert both a direct and an indirect influence on a firm's demand for flexible contracts. Unions and workers' representatives may obtain some direct involvement in the shaping of the firm's hiring policies through participation in firm-level specific agreements on issues not already covered by NCLAs, or further specifying the sector-wide dispositions to local circumstances. According to CNEL (2007), "numerical flexibility" and, in particular, "issues related to the use of atypical contracts" were covered in almost 50\% of company-level agreements in the period 1998-2006, albeit there is uncertainty about the exact content of the agreements. Union influence may also be exerted through more informal consultation and involvement practices. This channel is likely to be relevant at the productive-unit level between workers' representatives and intermediate managers -especially in small-medium size firms- though no systematic information is currently available on the spread of such practices (see Cerruti, 2011). Finally, a union might also influence a firm's use of temporary workers indirectly, e.g. by activating firm's strategies aiming at countervailing an increase in labor costs associated with the presence of a union (e.g., Abraham and Taylor, 1996).

\footnotetext{
${ }^{9}$ Firms can also employ collaboration contracts ('collaborazioni'), under which the workers are to be formally considered as self-employed although in some cases they perform tasks equal to those of employees of the firm. Because of reduced social security contributions, no training obligations and the possibility to extend and repeat these contracts at will, firms stand to benefit from this type of contract, which represents around 3\% of the workforce. Temporary agency contracts are also available to firms. Because of agency fees, the cost of these external workers is higher than in the case of permanent contracts, partly offset by lower hiring and firing costs. Their share in the workforce is still limited in Italy, at only 1.5 percent. We do not consider these two types of contracts because they are not formally employee of the firm, and because it is not possible to distinguish in our data those collaboration or agency workers that actually replace employees in the firm from those who carry out some 'genuine' consultancy or have short-term labor relations with the firms.
} 


\section{Data and descriptive statistics}

The empirical analysis is based on the Employer and Employee Survey (RIL) conducted by ISFOL in 2005 and 2007 on a nationally representative sample of firms operating in the non-agricultural private sector. The RIL survey collects a rich set of information on personnel organization, industrial relations and other workplace characteristics. In particular, the RIL allows us to distinguish between the two different typologies of temporary contracts according as to whether a training clause is explicitly considered. We define as "training temporary contracts" (i.e., 'contratti a causa mista') any apprenticeship contracts, training and work contracts ('contratti di formazione lavoro') and job insertion contracts ('contratti di inserimento lavorativo'). The term "non-training temporary contracts" ('Contratti a tempo determinato') refers to any other type of fixed-term contracts that contain no training clause.

In order to link information on workplace characteristics to indicators of firm performance and economic volatility, the RIL dataset is merged with annual balance sheets and income statement data from the AIDA archive. The merge is carried out through unique company tax codes. As AIDA only covers limited companies with turnover over 100,000 euros, the RIL-AIDA merged sample restricts the analysis to limited companies above this (rather minimal) threshold.

Given our focus, we also exclude firms with fewer than ten employees, to retain only those firms characterized by a minimum level of organizational structure and for which the share of employees in different types of contracts can be meaningfully computed. Further, very small firms are rarely characterized by union representation. Our final sample includes over 6600 firms.

Descriptive statistics on the pooled 2005-2007 RIL-AIDA sample are displayed in Table 1: the overall share of fixed-term contracts comes to $9.8 \%$, which can be split into the share of nontraining contracts $(6.1 \%)$ and the share of training contract $(3.7 \%)$. As for the other variables of interest, we created a dummy variable ("union" for short) indicating whether workers have established any form of workers' representation at the workplace that is legally entitled to 
participate in the firm-level bargaining process. ${ }^{10}$ Such workplace representation is at work in about $40 \%$ of the firms.

Another important variable in the analysis is the volatility measure, which is computed as the average standard deviation of log sales over the period 1997-2005, calculated at the 3-digit classification of economic activity (NACE, over 450 sectors). We used the AIDA dataset to compute our measure of volatility, as this dataset has yearly information on firms' sales and numbers of employees (but not on unionization and contract types) for incorporated businesses in Italy over a relatively long time period. Note that our measure of demand volatility is computed at the sectoral level, rather than at the firm level, which helps minimize endogeneity concerns related to this variable. Table 1 shows that the demand volatility measure has a mean equal to 0.4 in the sample. Table 1 also sets out the descriptive statistics for all the other control variables used in the regression analysis.

\section{Econometric analysis}

Our econometric analysis is performed using regression models to estimate the following equation:

$$
T C_{i t}=\beta_{1} \text { vol }_{c t}+\beta_{2} \text { union }_{i t}+\beta_{3} \text { vol }_{c t} \times \text { union }_{i t}+X_{i t} \delta+\varepsilon_{i t} \quad \text { with } t=2005,2007 .
$$

$T C_{i t}$ denotes the share of workers with a temporary contract in firm $i$ at time $t, v_{c} l_{c t}$ is our measure of a firm's output demand volatility (in the sector $c$ to which firm $i$ belongs), and union $n_{i t}$ is a dummy variable indicating union presence at the workplace. $\operatorname{Vol}_{c t}{ }^{*} u n i o n_{i t}$ is an interaction term capturing the effect of the interplay between volatility and workplace unionization on the share of fixed term contracts.

\footnotetext{
10 In accordance with the institutional framework presented in section 3, we take as an indicator of unionization the presence of either RSUs or RSAs at the workplace.
} 
The vector $X_{i t}$ contains firm-level control variables that may affect the dependent variable and may be correlated with workplace unionization and volatility. In all the models reported below we have included the following control variables: the share of female workers, the shares of blue- and white-collar workers, the firm's age (in years), firm size dummies (3 classes defined in terms of employees), sector dummies (10 industries), geographical area dummies (4 macro regions) and a dummy for year 2007. In none of the cases did experimentation with models containing sub-sets of these control variables have any appreciable effect on the estimates of our relevant variables, and it is therefore not reported. Finally, $\varepsilon_{i t}$ is an idiosyncratic error whose properties are specified in the next section, depending on the chosen econometric approach.

\subsection{Endogeneity and methodological issues}

A major concern when estimating an equation like (1) lies in the potential endogeneity of a firm's union status. The presence of a union in a firm is influenced by many observed and unobserved firm characteristics, and by the institutional features of the industrial relations operating at the national and local level. In particular, a number of variables might be expected to affect both a firm's union status and the propensity to hire temporary workers. Examples of such variables could be firm profitability or managerial culture and ability. Failing to control for these factors may potentially bias the relevant estimates. For instance, a firm culture promoting highperformance resource management practices and high investment in human capital might generate both a limited use of temporary workers (particularly of the "buffer" type) and a cooperative environment conducive to worker representation, and hence union presence.

The first solution considered in order to address the potential endogeneity of union status is to resort to an instrumental variable approach, which can potentially deal with time-invariant and time-variant omitted variable biases, including measurement error in union status. Of course a major challenge - still largely ubiquitous in the literature on the effects of unions - lies in finding 
suitable instruments. Ideally, we would like to instrument union status in a first-differenced model. This empirical strategy would cope with firm-level time-invariant unobserved heterogeneity (by first differentiating equation (1)), while controlling for time-specific omitted variables and measurement error in union status (via IV of the first differentiated model). However, it is no simple task to find valid instruments for the change in a firm's union status, and for this reason we had to abandon the panel IV approach.

Instead, we resort to a simpler IV framework, in which a firm's union status is instrumented by the two-year lagged mean unionization at the three digit industry and region level. Clearly, this IV strategy means limiting analysis to the 2007 data sample, since our main instrument is derived using the 2005 wave. ${ }^{11}$ To increase efficiency, our preferred IV specification also uses the four-year lagged industry profit per employee as an additional instrument. ${ }^{12}$

We believe that both variables make for reasonable IV candidates. Consider lagged mean unionization. First, most temporary contracts are of very short duration, on average less than a year. Hence, a two-year lag in industry-level unionization is not expected to have any direct impact on the current use of temporary employment, once current unionization at the workplace is controlled for. While longer lags would, in principle, be desirable, we cannot construct them on the basis of the available data. ${ }^{13}$ Second, mean unionization at the industry and territorial level is a strong predictor of current workplace unionization. Empirically, this is clearly supported by the first-stage statistics that we report below. More importantly, the predictive power of the instrument is to be expected in light of the institutional framework discussed above. According to Italian law, workplace unionization is to emerge out of the initiative of a firm's workers. Setting up the process leading to workers' representation, however, requires expert knowledge and

\footnotetext{
11 No other dataset is currently available for Italy to compute mean unionization at a finely disaggregated level.

12 'Profit per employee' is here measured by the Gross Operating Surplus available in AIDA, divided by the firm's number of employees, and then averaged at the three-digit industry level.

13 The results by Salvadori (2012), showing that firms under the threat of unionization do not increase their demand for temporary employment, also offer evidence that reverse causality may not be a major concern.
} 
operational support which the local structures of the union confederations are able and willing to provide. In short, past unionization at the industry and territorial level acts as an incubator for workplace unionization. Moreover, the single channel of representation entails that union officials, in most cases external to the firm, are actively involved in consultation and negotiation activities. ${ }^{14}$

Turning to past firm profitability, this is also a strong predictor of current unionization. ${ }^{15}$ This is to be expected: past firm profitability is a clear determinant of unionization, as unions can only expect to share rents where rents are sizeable. A four-year lag in profitability should suffice to remove concerns about possible direct effects on the current share of temporary workers. To make our case even more compelling, we experiment with specifications that include and exclude current firm profitability from the list of controls.

A second solution to the potential endogeneity of union status is to assume that omitted variables are time-invariant. Hence, an individual-specific intercept, $\alpha_{i}$ is added as a component of the error term in equation (1); $\alpha_{i}$ can be freely correlated with union status or other RHS variables in the model. In such a framework, consistent estimates may be obtained via linear models with fixed effects (FE). Since firms are observed in two points in time (2005 and 2007) in our data, we can estimate fixed-effect models. However, we have to recognize that limited "within" variability and the attenuation bias resulting from measurement errors -especially in fixed-effect models- are a challenge for this identification strategy to produce reliable results.

Clearly, both the IV and the FE approach show certain weaknesses in the present application and given the available data. We therefore take the results of either approach to be reliable only if

\footnotetext{
14 In the text of the 1993 Tripartite Agreement, it is explicitly mentioned that the competent territorial structures of the trade union associations (that have signed the NCLA applied in the productive unit) participate in collective bargaining within the firm alongside workers' representatives.

15 Salvadori (2009) reports IV estimates of the effect of unions on the probability of firms employing any temporary workers, using a 6-year lagged employment as an instrument for union status. The argument in favor of such an instrument is that lagged employment can be expected to be correlated with current union status, because union status is a persistent feature of the workplace and employment size is a known determinant of union status. However, our computations showed that long lags of employment (which are available from the information contained in AIDA) are only weak instruments in our application, with first-stage F statistics that never exceed critical values at conventional levels.
} 
additional support is provided by the alternative identification strategy. For this reason, our empirical analyses are conducted using both approaches in parallel.

Before turning to the results, we will briefly discuss the pros and cons of using linear models (as in our IV and FE regressions) as opposed to nonlinear models such as Tobit regressions. The latter are a standard choice to account for the double-censored nature of our dependent variable, the fraction of workers with a fixed-term contract lying between zero and one by construction (Houseman, 2001; Cappelli and Neumark, 2004; Lee and Kim, 2005). Linear models do not account for the censored nature of the dependent variable; on the other hand, however, they are better placed for dealing with the potential endogeneity of right-hand side variables and provide a simpler framework to compute average marginal effects in the presence of variable interactions (Angrist and Pischke, 2009).16 For these reasons, our main analysis is conducted through linear models. Nevertheless, for robustness we also report in the Appendix the results obtained with both standard and random-effect Tobit models, which are consistent with the results derived using linear models.

\subsection{Econometric Results}

Table 2 displays the estimated coefficients of equation (1), focusing for the sake of brevity only on the most relevant variables. ${ }^{17}$ The first column of Table 2 sets out the OLS coefficients of a simpler version of equation (1) that omits the interaction term. It shows that economic volatility has a positive and statistically significant effect on the utilization of flexible contractual arrangements, consistently with the previous literature arguing that volatility encourages firms to employ temporary workers to adjust the labor input more easily. More specifically, a one standard deviation increase in volatility is associated with an increase of around 2 percentage points in the

\footnotetext{
${ }^{16}$ Note that the existing IV Tobit models (see for instance IVTOBIT implemented in STATA) require that the endogenous variable be continuous, and hence are not suitable for dealing with the endogeneity of dummy-type RHS variables, like our union status indicator.

17 The estimated coefficients of the control variables are briefly discussed in the online appendix, where we compare our results with those from standard and random-effect Tobit models.
} 
use of temporary contracts. This represents quite a sizable effect, amounting to a nearly $20 \%$ increase with respect to the baseline share of temporary contracts standing at $9.8 \%$.

Column 1 also shows that the presence of a union in the workplace is associated with a lower use of temporary contracts (-2.3 percentage points). As argued above, one possible interpretation of this finding concerns the fact that temporary employees are less likely to be unionized and engaged in industrial relations than permanent employees. This implies that hiring workers on a temporary basis may significantly weaken union bargaining power and its representativeness in industrial relations. If this is indeed so, then the unions would discourage the use of fixed term contracts to favor outcomes for the "insiders" in future bargaining negotiations (Booth, 1995; Bentolila and Dolado,1994).

To gain further insights into these mechanisms, we re-estimate equation (1) by OLS including the interaction term in column 2. In this case the unions no longer seem to play a direct role in discouraging the use of fixed term contracts: the estimated coefficient turns positive, though it is not statistically significant. However, it is the coefficient of the interaction term that is now negative and statistically significant. This suggests that a union's opposition to the use of temporary employment is partly driven by economic uncertainty. In the presence of incomplete contracts, highly volatile economic environments require more frequent renegotiation of wage and labor conditions at the workplace. In such conditions, the unions may oppose an intensive use of fixed-term contracts to prevent the weakening of their bargaining power, which would in turn negatively affect the insiders' outcomes in future bargaining rounds.

Columns (3) to (8) of Table 2 show the estimates from a series of IV models. ${ }^{18}$ Column (3) refers to the specification with no interaction between union and volatility. Workplace unionization is treated as an endogenous variable and instrumented with the two-year lagged mean unionization

\footnotetext{
18 In the IV models standard errors are clustered at the 3-digit industry and regional level. This choice is consistent with the variability of one of the instruments. Results using a more parsimonious clustering (at the firm level) are consistent with the ones proposed, and are available on request.
} 
at the industry and regional level, and the equation is exactly identified. The estimates in column (3) confirm the previous finding that volatility has a positive impact on the demand for temporary workers. Note that the direct union effect is now positive, though not statistically significant.

The specification in columns (4) includes an endogenous interaction term, which has to be treated as an endogenous variable in the estimation. The additional instrument is given by the interaction between volatility and the two-year lagged mean unionization variable, and the equation is again exactly identified. The estimates largely confirm our previous results: a positive impact of volatility and a negative interaction term between volatility and union presence. Additionally, the direct union effect is positive and statistically significant at the $10 \%$ level.

The specification in column (5) adds the four-year lagged industry profits as an additional instrument. The equation is now over-identified and it is possible to provide a test of overidentifying restrictions. As shown by the Hansen J statistics, we are unable to reject the null hypothesis for the over-identifying restrictions. The results are very similar to the ones in the previous column, but now the effect of union is also statistically significant at conventional levels.

In the remaining columns from (6) to (8) additional controls are progressively included for robustness. We begin in column (6) by controlling for current profit per worker, measured at the firm level by the gross operating margin divided by the number of workers. Once a firm's current profitability is controlled for, past industry profits are more likely to be redundant in equation (1) and hence to constitute a valid instrument.

In column (7) we add a large number of dummies (around 200 dummies) for the specific NCLAs applied in the firm, the aim being to control for more detailed industry characteristics than in previous specifications. The dummies also account for any influence arising from the sectorwide bargaining, and in consideration of the hierarchical nature of the Italian two-tier bargaining regime. For instance, Italian labor law (Legislative Decree 368/2001) delegates to the various NCLAs the role of fixing the maximum percentage of fixed-term workers in a firm's workforce. It is 
in fact possible to include a large number of NCLA dummies in our IV models as the definition of these NCLAs is related to, but not entirely overlapping with, the three-digit industry classification that we use to compute our instruments. The estimates and diagnostics in column (7) are once again supportive of our earlier conclusions. So also is our final IV model, in column (8), which adds the firm's capital intensity (the stock of the material fixed assets from the firm's balance sheets, divided by the number of employees) to proxy for a firm's technology.

Next, we turn to a series of linear fixed-effect models in columns (9) to (12) of Table 2. As discussed earlier, fixed-effect models deal with omitted variable bias arising from time-invariant unobserved heterogeneity, and provide an alternative identification strategy to the IV models presented so far. We start in column (9) with our baseline FE model, which includes all the time time-varying controls as in the OLS and IV models. Note that because the NCLAs applied in a particular firm constitute a time-invariant attribute, all our FE models also absorb the specific features of the sectoral collective bargaining and other time-invariant industry characteristics. The estimates are in line with those reported earlier. When comparing the results in column (9) with the OLS estimates of column (2), it is worth noting that controlling for time invariant unobserved heterogeneity has the effect of increasing the coefficient of the direct union effect, suggesting that firm unobserved heterogeneity, proxy for the quality of the firm, is positively correlated with union presence and negatively correlated with the share of temporary contracts, as expected.

In column (10) we attempt to control for idiosyncratic productivity shocks that might be correlated to both the firm's demand for temporary workers and workplace unionization. Productivity shocks are typically not observed by the econometrician but might be at least partly anticipated by firms and workers. One simple way to deal with this concern is to rely on a firm's use of raw material as a proxy for idiosyncratic shocks. Echoing the control function approach used in the estimation of firm productivity equations (e.g., Levinsohn and Petrin, 2003), the idea is that firms increase their use of raw material when they face an increase in the demand for their 
output. Column (11) further enriches the list of controls by adding industry average consumption of intermediate goods (at the three digit NACE level), on top of a firm's own use of the same goods. Finally, in column (12) we add a firm's total employment and current profit (in logs) as additional controls. ${ }^{19}$

The overall picture is fairly reassuring, with all the qualitative and to a large extent also the quantitative results being similar to the IV results discussed earlier. ${ }^{20}$

\section{Contract type matters: training temporary contracts $v s$. non-training temporary contracts}

In this section we investigate the existence of any relevant heterogeneity across two different types of temporary contracts, thereby providing further insights for an understanding of the findings reported so far. Following the discussion in section 5, we present in parallel and compare the results based on both IV models and FE models.

We begin by discussing the results of separate IV estimations of equation (1) for non-training temporary contracts (column 1) and for training temporary contracts (column 2) in Table 3. The specification and list of instruments is the same as before (see column 6 in Table 2).

Both sets of estimates clearly show that the effects of volatility and union presence are markedly heterogeneous across contracts types. The effect of volatility is large and statistically significant only for non-training temporary contracts, while it is ten times smaller and not statistically significant for training temporary contracts. This finding is consistent with the different role of the two contracts from the firm's standpoint. In coping with a volatile economic environment in the presence of a high level of protection for permanent workers, it is cost-effective for firms to rely on non-training temporary contracts rather than contracts with a training clause, as the training investment would be lost upon the temporary worker's dismissal.

\footnotetext{
19 Profits, material and the stock of capital are all variables computed, for each firm and year, from the AIDA dataset. Hence, they are firm-specific and time-varying.

20 As a robustness check we include in the Appendix the estimates derived using standard and random-effect Tobit models, which also provide a consistent picture of the results obtained using linear models.
} 
The effect of unions is positive and statistically significant for non-training contracts and negative and not significant for training contracts. This finding can also be rationalized on the basis of the different nature of the two types of contracts, and may reflect both the interests of the unions and the firms. The unions have an interest in the presence of a positive share of the nontraining temporary contracts, which can offer a sort of protection to permanent workers. On the other hand, the training contracts cannot credibly work as a buffer to protect insiders, as firms will be less willing to sacrifice their training investments to accommodate the interests of the union. Moreover, in the presence of a union, firms, too, may have an interest in hiring on the cheaper type of temporary contracts (i.e., those that carry no training obligations) to countervail any uniondriven labor cost push.

The sign of the interaction effect further qualifies these findings, suggesting that in a volatile economic environment the unions become more concerned about the loss of bargaining power due to the high fraction of temporary workers, and start opposing their presence. While temporary contracts are used by firms to cope with volatile economic environments, temporary workers are less prone to engage in industrial relations (typically organized by permanent workers), and their presence is thus expected to weaken the strength or "voice" of the unions in the bargaining process. This is conjectured to be the case mainly in highly volatile environments as employment conditions are negotiated more frequently in such environments.

This effect can be quantified by computing the union effect at different values of volatility. Using the estimates in the richer specification of column 3, we obtain that unions increase the proportion of non-training fixed-term workers by 3.4 percentage points when volatility is low, i.e. at the first decile of the volatility distribution. However, the same effect is rapidly reduced in the presence of higher volatility: it is virtually zero if volatility is at the median and becomes negative 
when volatility is high (at the $90^{\text {th }}$ percentile). ${ }^{21}$ As for the case of training temporary contracts, column 2 shows that neither the direct union effect nor the interaction effects are statistically significant.

In columns (3) and (4) we display the estimates of richer specifications that add the NCLA dummies. All our results for non-training temporary contracts are confirmed, whereas no union or volatility effects are detected for training temporary contracts.

The rest of Table 3, columns (5) to (8), shows the results obtained with selected specifications of FE models, separately estimated for the two types of temporary contracts. Columns (5) and (6) are based on a rich specification that controls for the same baseline list of controls as in Table 2, plus firm-level profits per workers and usage of intermediate goods (log materials). Columns (7) and (8) report the results for corresponding models that also control for a firm's capital stock and total employment. Once again, a consistent picture emerges with respect to the results discussed earlier, in terms both of the sign of our relevant variables and, though to a lesser extent, of the estimate magnitudes.

\section{Conclusions}

This paper shows that workplace unionization has a positive impact on the firms' propensity to use temporary employment, although the effect is reduced by the presence of high economic volatility in the firm's product market. This conclusion, however, crucially depends on the type of temporary contracts. The presence of a union at the workplace has a positive effect on the firm's use of non-training temporary workers, because they constitute a protective buffer for permanent/insider workers. At the same time, firms may want to hire non-training temporary workers in the presence of unions, as a way to reduce direct labor costs and labor turnover costs

\footnotetext{
21 Given the high significance of the underlying estimated coefficients, all these average treatment effects are also statistically significant.
} 
deriving from strict protection for permanent workers. However, in the presence of high demand volatility, the unions become increasingly concerned about the loss of their bargaining power, and the union effect is reduced, becoming negative for high levels of volatility.

Conversely, workplace unionization exerts no effect on the share of training temporary workers. We argue that this finding can be accounted for by the different nature of this contractual arrangement. Training contracts are institutionally designed to favor more efficient screening processes and investments in job-specific skills, rather than coping with the volatility in a firm's economic environment. Not surprisingly, for these contracts an effect of "stepping stones" towards regular contracts is often found by the empirical literature; on the contrary, non-training fixed term contracts are more often associated with "dead-end jobs" (Berton et al., 2011; Lilla and Staffolani, 2012).

Overall, our paper provides new insights into the role played by worker representation at the workplace in affecting human resource management and firms' personnel policies. Moreover, our results might provide some additional support to the claims that the bargaining process between firms and trade unions at the workplace tends to favor the interest of the permanent workers, as traditionally formalized in the insider-outsider literature.

Finally, our paper contributes to the literature analyzing the labor market effects of bargaining decentralization. In recent years, policy prescriptions from many national and international institutions have recommended a shift away from nation-wide sectoral bargaining to firm level bargaining, in an attempt to recover flexibility and competitiveness for the firms in a number of countries, including Italy.

Our results suggest that an unintended, and understudied, consequence of such prescriptions might be an increase in labor market duality, as unionization at the workplace and decentralized bargaining may be accompanied by an increase in the use of buffer-type temporary contracts. Whether this is the result of a direct effect of union behavior, which might encourage the use of 
temporary workers to protect the interests of insider permanent workers, or an indirect effect of union presence on the firms' strategies to countervail a union-driven wage push, our data offer no decisive evidence. This is a limitation that we hope future research might be able to overcome.

\section{References}

Abraham K. G. and Taylor S. K. (1996) "Firms' Use of Outside Contractors: Theory and Evidence", Journal of Labor Economics, 14, 3, pp. 394-424.

Addison J. (2014) “The consequences of trade union power erosion", IZA World of Labor, n. 68.

Angrist J., Pischke S. (2009) "Mostly harmless econometrics: an empiricist's companion," Princeton, New Jersey, USA: Princeton University Press.

Autor D. H. (2003) "Outsourcing at will: The contribution of unjust dismissal doctrine to the growth of employment outsourcing", Journal of Labor Economics, 21(1), 1-42.

Battisti M., Vallanti G. (2013) “Flexible Wage Contracts, Temporary Jobs and Firm performance: Evidence from Italian Firms", Industrial Relations, vol. 52(3), pp 737-764.

Bentolila S. and Saint-Paul G. (1994) "A model of labor demand with linear adjustment costs", Labour Economics, vol. 1(3-4), pages 303-326.

Bentolila S. and Dolado J. J. (1994) "Labour flexibility and wages: lessons from Spain”, Economic Policy, 18, p.55-99.

Berton F., Devicienti F., Pacelli L. (2011) “Are temporary jobs a port of entry into permanent employment? Evidence from matched employer-employee data", International Journal of Manpower, 8, pp.879-899.

Blanchard, O., Landier, A. (2002) "The perverse effect of partial labour market reform: fixed-term contracts in France", Economic Journal, 112, p. 214-244.

Boeri T., Garibaldi P. (2007) “Two tier reforms of employment protection: a honeymoon effect?", Economic Journal, 117, p. 357-385.

Boeri T. (2012) "Institutional reforms and Dualism in European labor markets", in Ashenfelter O. Card D. (eds) Handbook of labor economics, vol. 4b, North Holland, Amsterdam, pp. 1173-1236.

Booth A. L. (1995) The Economics of Trade Union. Cambridge: Cambridge University Press.

Booth A. L. and Francesconi M. (2003) “Union coverage and non-standard work in Britain”, Oxford Economic Papers, 55 (3), 383.416.

Booth A.L., Francesconi M. and Frank J. (2002) "Temporary jobs: Stepping stones or dead-ends?", Economic Journal, 112, p. 189-213.

CNEL (2007) “Lineamenti della contrattazione aziendale nel periodo 1998-2006", Rapporto, Roma.

Caggese A., Cunat V. (2008) "Financing Constraints and Fixed-term Employment Contracts", The Economic Journal, 118, 2013-2046. 
Cappellari L., Leonardi M., Dell'Aringa C. (2012) “Temporary Employment, Job Flows and Productivity: A Tale of Two Reforms", The Economic Journal, 122, Issue 562, pp. F188-F215.

Cappelli P., Neumark D. (2004) “External Churning and Internal Flexibility: Evidence on the Functional Flexibility and Core-Periphery Hypotheses", Industrial Relations, 43, 1, p. 148-182.

Cella G.P., Treu T. (1999) Relazioni industriali e contrattazione collettiva, Il Mulino, Bologna.

Cerruti G.C. (2011) “L'evoluzione della contrattazione aziendale nella provincia di Torino tra il 1993 e il 2007", Quaderni di Rassegna Sindacale, no. 2, pp. 259-302.

Costain J., Jimeno J. F., Thomas C. (2010) “Employment Fluctuations in a Dual Labor Market", Banco de España Working Paper 1013.

Damiani M, Ricci A., (2014) Decentralised bargaining, and performance related pay: Evidence from a panel of Italian firms, International Journal of Manpower, vol. 35, 7, pp. 1038-1058.

Damiani M, Pompei F., Ricci A. (2014) "Temporary job protection and productivity growth in EU economies", International Review, forthcoming http:/ / onlinelibrary.wiley.com/journal/10.1111/(ISSN)1564-

D'Amuri F., Giorgiantonio C. (2015) “The Institutional and Economic Limits to Bargaining Decentralization in Italy", IZA Policy Paper, n. 98.

Francesconi M., Garcia-Serrano C. (2004) “Unions and flexible employment in Britain and Spain: A descriptive note", Industrial relations, 43, 874-882.

Freeman R., Medoff J.L. (1984) What Do Unions Do?, Basic Books, New York.

Gramm C. L., Schnell, J. F. (2001) "The use of flexible staffing arrangements in core production jobs“, Industrial and Labor Relations Review, 54, 2, pp. 245-258.

Heery E. (2004) "The trade union response to agency labour in Britain", Industrial Relations Journal 35(5), 434-450.

Holmlund B., Storrie, D. (2002) "Temporary work in turbulent times: the Swedish experience", Economic Journal, 112, pp. 245-269.

Houseman S. (2001) "Why employers use flexible staffing arrangements: evidence from an establishment survey", Industrial and Labor Relations Review, 55, 1, pp. 149-170.

Lee I., Kim D. (2005) "Unions and the Use of Flexible Staffing in Korea: Evidence from an Establishment Survey", International Economic Journal, 19, 2, pp. 223-234.

Levinsohn J., Petrin A. (2003) "Estimating Production Functions Using Inputs to Control for Unobservables", The Review of Economic Studies, 70(2): 317-341.

Lotti A., Viviano E. (2012) "Temporary workers, uncertainty and productivity”, The Society of Labor Economists, mimeo.

OECD (2008) Employment Outlook. Paris: OECD.

Salvatori A. (2012) "Union threat and non-union employment: A natural experiment on the use of temporary employment in British firms", Labour Economics, vol. 19(6), pp 944-956

Salvatori A. (2009) "What Do Unions Do to Temporary Employment?," IZA Discussion Papers 4554 . 
Saint-Paul G. (1996) Dual Labor Markets: A Macroeconomic Perspective. Cambridge, MIT Press.

Visser J. (2002) "The first part-time economy in the world: A model to be followed?", Journal of European Social Policy, 12, 23-42. 
Table 1. Descriptive statistics

\begin{tabular}{|c|c|c|c|c|}
\hline Variable & mean & std dev & $\min$ & $\max$ \\
\hline Share of temporary contracts & 0.098 & 0.149 & 0 & 1 \\
\hline Share of non-training fixed-term Contracts & 0.061 & 0.134 & 0 & 1 \\
\hline Share of training temporary contracts & 0.037 & 0.076 & 0 & 1 \\
\hline Union & 0.400 & 0.491 & 0 & 1 \\
\hline Volatility & 0.398 & 0.201 & 0.066 & 1.492 \\
\hline Share of female workers & 0.323 & 0.267 & 0 & 1 \\
\hline Share of white collars & 0.407 & 0.297 & 0 & 1 \\
\hline Share of blue collar & 0.539 & 0.313 & 0 & 1 \\
\hline Share of trainees & 0.200 & 0.316 & 0 & 1 \\
\hline Firm age (years) & 22.229 & 16.018 & 0 & 150 \\
\hline Ln(value added per employee) & 10.700 & 0.619 & 8.378 & 13.141 \\
\hline Ln(n. of employees) & 3.246 & 0.852 & 2.398 & 9.414 \\
\hline \multicolumn{5}{|l|}{ Macro-region } \\
\hline North-West & 0.368 & 0.482 & 0 & 1 \\
\hline North-East & 0.260 & 0.439 & 0 & 1 \\
\hline Centre & 0.196 & 0.397 & 0 & 1 \\
\hline South & 0.177 & 0.381 & 0 & 1 \\
\hline \multicolumn{5}{|l|}{ Sector of activity } \\
\hline $\begin{array}{l}\text { Quarrying, water, gas and electricity } \\
\text { distribution }\end{array}$ & 0.008 & 0.088 & 0 & 1 \\
\hline Textiles & 0.129 & 0.335 & 0 & 1 \\
\hline Manufacturing & 0.180 & 0.384 & 0 & 1 \\
\hline Mechanics & 0.148 & 0.355 & 0 & 1 \\
\hline Construction & 0.161 & 0.368 & 0 & 1 \\
\hline Trade, hotels and restaurants & 0.172 & 0.377 & 0 & 1 \\
\hline Transport and communication & 0.040 & 0.196 & 0 & 1 \\
\hline Business services & 0.073 & 0.260 & 0 & 1 \\
\hline Education, health and public services & 0.090 & 0.286 & 0 & 1 \\
\hline \multicolumn{5}{|l|}{ Year effects } \\
\hline 2007 & 0.447 & 0.497 & 0 & 1 \\
\hline N. of observations & 6655 & & & \\
\hline
\end{tabular}

Notes: sample weights used. 
Table 2. OLS, IV and Fixed-effect models. All temporary workers.

\begin{tabular}{|c|c|c|c|c|c|c|c|c|c|c|c|c|}
\hline & \multicolumn{2}{|c|}{ OLS models } & \multicolumn{6}{|c|}{ IV models } & \multicolumn{4}{|c|}{ Fixed-effect models } \\
\hline & $(1)$ & (2) & (3) & (4) & (5) & (6) & (7) & $(8)$ & (9) & (10) & (11) & $(12)$ \\
\hline Volatility & $0.101^{* * *}$ & $0.122^{* * *}$ & $0.136 * * *$ & $0.217 * * *$ & $0.250 * * *$ & $0.251^{* * *}$ & $0.125^{* * *}$ & $0.127 * * *$ & $0.100 * *$ & $0.157 * * *$ & $0.146 * * *$ & $0.144 * * *$ \\
\hline (s.e.) & 0.019 & 0.022 & 0.025 & 0.042 & 0.046 & 0.046 & 0.029 & 0.029 & 0.051 & 0.058 & 0.058 & 0.058 \\
\hline Union & $-0.023 * * *$ & 0.004 & 0.012 & $0.066^{*}$ & $0.088 * *$ & $0.093 * *$ & $0.068 * *$ & $0.065 * *$ & $0.037 * * *$ & $0.042^{* * *}$ & $0.040 * * *$ & $0.041^{* * *}$ \\
\hline (s.e.) & 0.004 & 0.009 & 0.024 & 0.037 & $\begin{array}{c}0.040 \\
-\end{array}$ & $\begin{array}{l}0.040 \\
-\end{array}$ & 0.034 & 0.034 & $\begin{array}{c}0.014 \\
-\end{array}$ & $\begin{array}{c}0.017 \\
-\end{array}$ & 0.017 & 0.017 \\
\hline Volatility*Union & & $-0.070 * * *$ & & $-0.251^{* *}$ & $0.271^{* * *}$ & $0.277 * * *$ & $-0.192 * * *$ & $-0.188 * * *$ & $0.100 * * *$ & $0.125^{* * *}$ & $-0.121 * * *$ & $-0.123 * * *$ \\
\hline (s.e.) ( ) & & 0.024 & & 0.093 & 0.105 & 0.105 & 0.073 & 0.074 & 0.031 & 0.039 & 0.039 & 0.039 \\
\hline Constant term & & & 0.047 & 0.154 & 0.155 & $0.504 * * *$ & $0.612 * * *$ & $0.658 * * *$ & -0.002 & $-0.011^{*}$ & $-0.013 * *$ & $-0.013^{* *}$ \\
\hline (s.e.) & & & 0.089 & 0.092 & 0.094 & 0.155 & 0.117 & 0.119 & 0.005 & 0.006 & 0.006 & 0.006 \\
\hline Controls: & yes & yes & yes & yes & Yes & yes & yes & yes & yes & yes & yes & yes \\
\hline $\begin{array}{l}\text { Additional } \\
\text { controls: }\end{array}$ & & & & & & $\begin{array}{l}\text { current } \\
\text { profit per } \\
\text { worker }^{4}\end{array}$ & $\begin{array}{c}\text { as in (6) } \\
\text { plus } \\
\text { dummies } \\
\text { for NCLAs }\end{array}$ & $\begin{array}{l}\text { as in (7) } \\
\text { plus log of } \\
\text { capital per } \\
\text { worker }\end{array}$ & & $\begin{array}{l}\text { material } \\
\text { (in log) }\end{array}$ & $\begin{array}{l}\text { as in }(10) \\
\text { plus } \\
\text { industry } \\
\text { mean } \\
\text { material }^{5}\end{array}$ & $\begin{array}{c}\text { as in (11) } \\
\text { plus log } \\
\text { employment } \\
\text { and log } \\
\text { current } \\
\text { profit }\end{array}$ \\
\hline Instrument list ${ }^{1}$ : & & & $\mathrm{Z} 1$ & $\mathrm{Z} 2$ & $\mathrm{Z3}$ & $\mathrm{Z3}$ & $\mathrm{Z3}$ & $\mathrm{Z3}$ & & & & \\
\hline \multirow{2}{*}{\multicolumn{2}{|c|}{$\begin{array}{l}\text { Weak identification test } \\
\text { Sargan statistic }^{3}\end{array}$}} & & 90.57 & 80.65 & 45.87 & 44.44 & 87.16 & 86.06 & & & & \\
\hline & & & $\S$ & $\S$ & 1.228 & 1.297 & 0.320 & 0.337 & & & & \\
\hline p-value & & & $\S$ & $\S$ & 0.268 & 0.255 & 0.572 & 0.561 & & & & \\
\hline Observations & 6655 & 6655 & 3294 & 3294 & 3157 & 3157 & 3019 & 3019 & 2847 & 2247 & 2247 & 2247 \\
\hline
\end{tabular}

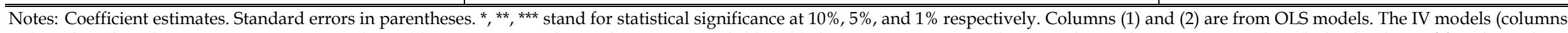

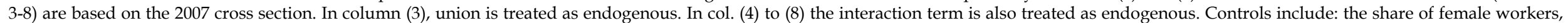

the shares of blue and white collar workers, the firm's age, firm size dummies (3 classes defined in terms of no. of employees), sector dummies (10), area dummies (4).

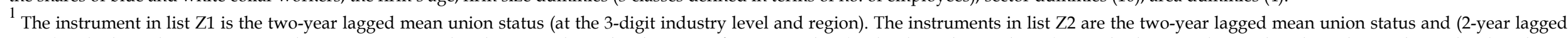
union)*volatility. The instrument in list Z3 is as in Z2 plus the 4-year lagged industry profits per worker (at the three-digit industry). Standard errors clustered at the 3-digit industry level in the IV models. ${ }^{2}$ Kleinbergen-Paap Wald F statistic. ${ }^{3}$ Over-identification test of all instruments. ${ }^{4}$ Profit measured as Gross operating margin. ${ }^{5}$ At ateco3 and region. $\S^{8}$ Equation is exactly identified. 
Table 3. Fixed-term contracts with and without training clause.

\begin{tabular}{|c|c|c|c|c|c|c|c|c|}
\hline & \multicolumn{4}{|c|}{ IV models } & \multicolumn{4}{|c|}{ Fixed-effect models } \\
\hline & (1) & $(2)$ & (3) & (4) & (5) & (6) & (7) & (8) \\
\hline & $\begin{array}{c}\text { Non-training } \\
\text { temporary } \\
\text { contracts }\end{array}$ & $\begin{array}{c}\text { Training } \\
\text { temporary } \\
\text { contracts }\end{array}$ & $\begin{array}{c}\text { Non-training } \\
\text { temporary } \\
\text { contracts }\end{array}$ & $\begin{array}{l}\text { Training } \\
\text { temporary } \\
\text { contracts } \\
\end{array}$ & $\begin{array}{c}\text { Non-training } \\
\text { temporary } \\
\text { contracts }\end{array}$ & $\begin{array}{l}\text { Training } \\
\text { temporary } \\
\text { contracts }\end{array}$ & $\begin{array}{l}\text { Non-training } \\
\text { temporary } \\
\text { contracts }\end{array}$ & $\begin{array}{l}\text { Training } \\
\text { temporary } \\
\text { contracts }\end{array}$ \\
\hline Volatility & $0.231^{* * *}$ & 0.023 & $0.125 * * *$ & 0.014 & $0.124 * *$ & -0.015 & $0.163 * *$ & -0.005 \\
\hline (s.e.) & 0.045 & 0.019 & 0.031 & 0.016 & 0.065 & 0.036 & 0.059 & 0.035 \\
\hline (s.e.) & 0.038 & 0.016 & 0.036 & 0.018 & 0.018 & 0.010 & 0.016 & 0.009 \\
\hline Volatility*Union & $-0.233 * *$ & -0.039 & $-0.184 * * *$ & -0.047 & $-0.134 * * *$ & 0.015 & $-0.139 * * *$ & 0.018 \\
\hline (s.e.) & 0.100 & 0.043 & 0.068 & 0.035 & 0.045 & 0.025 & 0.042 & 0.022 \\
\hline Constant & $0.344 * *$ & $0.201 * * *$ & $0.460 * * *$ & $0.244 * * *$ & 0.005 & $-0.011 * * *$ & -0.002 & $-0.012 * * *$ \\
\hline (s.e.) & 0.158 & 0.054 & 0.109 & 0.056 & 0.006 & 0.003 & 0.005 & 0.003 \\
\hline Usual controls & yes & yes & yes & yes & yes & yes & yes & yes \\
\hline Instrument list ${ }^{1}$ : & $\mathrm{Z3}$ & $\mathrm{Z3}$ & $\mathrm{Z3}$ & $\mathrm{Z3}$ & & & & \\
\hline Weak identification test ${ }^{2}$ & 47.098 & 44.939 & 47.098 & 44.939 & & & & \\
\hline Sargan statistic ${ }^{3}$ & 0.759 & 0.131 & 1.546 & 2.413 & & & & \\
\hline p-value & 0.3836 & 0.7171 & 0.2137 & 0.1204 & & & & \\
\hline Observations & 3151 & 3151 & 3013 & 3013 & 2239 & 2239 & 2239 & 2239 \\
\hline
\end{tabular}

Notes: Coefficient estimates. Standard errors in parentheses. Columns (1)-(4) are from IV models. Columns (5)-(8) are from fixed-effect models.

${ }^{1}$ The instruments in list Z3 are the two-year lagged mean union status, the interaction (2-year lagged union)*volatility and the 4-year lagged industry profits per worker (at the three-digit industry codes). Standard errors clustered at the 3-digit industry level in the IV models. ${ }^{2}$ Kleinbergen-Paap Wald F statistic. ${ }^{3}$ Over-identification test of all instruments. ${ }^{4}$ Profit measured as Gross operating margin. ${ }^{5}$ At ateco3 and region. ${ }^{\S}$ Equation is exactly identified. 


\section{Appendix (this material can be posted online if requested by the editor of the journal)}

\section{A1. Robustness checks: Tobit regressions}

In this appendix we include results obtained when using simple Tobit regressions to account for the double-censored nature of our dependent variable. The error term is here assumed to be normally distributed and uncorrelated with the explanatory variables included in (1).

The results are shown in Table A2. Models 1 and 2 provide Tobit estimates for the pooled sample, i.e. waves 2005 and 2007, which we refer to as pooled Tobit. The upper part of the table shows the average treatment effects (ATE), namely the change in the share of fixed term contracts associated with a unit change in a given covariate, averaged over the sample distribution of the other covariates in the model. Note that, because of the nonlinear nature of the model, computing the ATE of a variable like union status requires that information be used on both the direct effect of union (coefficient $\beta_{2}$ in equation (1)) and the interaction effect $\left(\beta_{3}\right.$ in (1)). The bottom part of the tables therefore also sets out the estimated coefficients for our main variables of interest. ${ }^{22}$

Model 1 shows that economic volatility has a positive and statistically significant effect on the utilization of flexible contractual arrangements, with an estimated ATE at 0.049 . This implies that a one standard deviation increase in volatility (equal to 0.2 ) raises the fraction of temporary workers in the firm by 1 percentage point $\left(=0.2^{*} 0.049\right)$. The estimates in Model 1 also show that the presence of a union in the workplace is associated with a lesser use of temporary contracts. Specifically, the ATE of union is a statistically significant reduction of 1 percentage point in the use of such contracts.

\footnotetext{
22 It may be interesting to compare the estimated OLS coefficients derived in the paper with the related coefficients obtained with the Tobit models of Table A2. The first thing to observe is the close similarity in the two sets of estimated coefficients. However, it is worth noting that the magnitude of the estimated ATE is somewhat different. So, while volatility raises the fraction of temporary employment by 0.1 in the OLS models, the impact is reduced by roughly half in the Tobit model. On the contrary, the union impact is stronger in the OLS than in the Tobit model. These differences in part relate to the non-linear nature of the Tobit model; specifically, the Tobit ATE is computed conditionally on the dependent variable lying in the zero-one interval, whereas no such restriction is enforced in computing the OLS ATE. This caveat should be borne in mind also when observing the IV estimates.
} 
We then estimate equation (1) with the inclusion of the interaction term (Model 2). The direct effect of unions is found to be positive, but not statistically significant. However, as in section 5, the coefficient of the interaction term is negative and significant.

In the rest of the Table, we also provide estimates of a random-effect Tobit model. In this case, an individual-specific random intercept $\alpha_{i}$ is added to equation (1) and is assumed to be normally distributed (with zero mean and variance $\sigma_{\alpha}$ ) and uncorrelated with the other explanatory variables. Hence, this model produces consistent estimates only under the rather strong assumption that the $\alpha_{i}$ are uncorrelated with union status. This is the main reason that led us to prefer the linear FE model in the main text, as in that case the $\alpha_{i}$ are allowed to be freely correlated with union status. The magnitudes of the estimated coefficients in the random-effect Tobit are very similar to those discussed earlier for the pooled Tobit, suggesting that unobserved firm heterogeneity is a relatively minor concern in this application.

Table A2 also displays the estimates of other control variables that could affect the use of fixedterm contracts: the log of value added, firm size dummies, sectoral specialization, geographical location and workforce composition. It emerges that firm productivity (measured by the log of value added) is the only variable that is negatively correlated with the use of fixed-term contracts. On the other hand, firm size, the share of female workers, the share of low-qualified workers (the omitted variable is constituted by executives) are positively associated with the use of total fixedterm contracts. The share of fixed-term contracts is also greater if firms are localized in North-East and Central regions. We do not include coefficients for industry dummies for the sake of space. 
Table A2: Tobit regression estimates. All temporary contracts.

\begin{tabular}{|c|c|c|c|c|c|c|c|c|c|c|c|c|}
\hline & \multicolumn{6}{|c|}{ Pooled Tobit } & \multicolumn{6}{|c|}{ Random-effect Tobit } \\
\hline & \multicolumn{3}{|c|}{ Model 1} & \multicolumn{3}{|c|}{ Model 2} & \multicolumn{3}{|c|}{ Model 3} & \multicolumn{3}{|c|}{ Model 4} \\
\hline variable & ATE & s.d.** & p-val. & ATE & s.d. ${ }^{* *}$ & p-val. & ATE & s.d. ${ }^{* *}$ & p-val. & ATE & s.d.** & p-val. \\
\hline Volatility * & 0.049 & 0.011 & 0.000 & 0.046 & 0.011 & 0.000 & 0.044 & 0.010 & 0.000 & 0.040 & 0.010 & 0.000 \\
\hline Union * & -0.010 & 0.003 & 0.000 & -0.011 & 0.003 & 0.000 & -0.009 & 0.003 & 0.001 & -0.009 & 0.003 & 0.000 \\
\hline \multicolumn{13}{|l|}{ Controls: } \\
\hline$\%$ female workers & 0.031 & 0.006 & 0.000 & 0.031 & 0.006 & 0.000 & 0.034 & 0.005 & 0.000 & 0.034 & 0.005 & 0.000 \\
\hline$\%$ white collar & 0.035 & 0.014 & 0.011 & 0.033 & 0.014 & 0.019 & 0.040 & 0.013 & 0.003 & 0.037 & 0.013 & 0.005 \\
\hline$\%$ blue collar & 0.051 & 0.014 & 0.000 & 0.048 & 0.014 & 0.000 & 0.051 & 0.013 & 0.000 & 0.049 & 0.013 & 0.000 \\
\hline$\%$ trained workers & 0.001 & 0.003 & 0.831 & 0.001 & 0.003 & 0.869 & 0.001 & 0.003 & 0.745 & 0.001 & 0.003 & 0.777 \\
\hline Firm age (years) & 0.000 & 0.000 & 0.041 & 0.000 & 0.000 & 0.037 & 0.000 & 0.000 & 0.050 & 0.000 & 0.000 & 0.046 \\
\hline $\ln$ (value added) & -0.012 & 0.002 & 0.000 & -0.012 & 0.002 & 0.000 & -0.014 & 0.002 & 0.000 & -0.014 & 0.002 & 0.000 \\
\hline $14<$ n. employees $<50$ & 0.027 & 0.004 & 0.000 & 0.028 & 0.004 & 0.000 & 0.027 & 0.003 & 0.000 & 0.027 & 0.003 & 0.000 \\
\hline $49<$ n. employees $<250$ & 0.050 & 0.005 & 0.000 & 0.049 & 0.005 & 0.000 & 0.048 & 0.005 & 0.000 & 0.047 & 0.005 & 0.000 \\
\hline N. employees $>249$ & 0.047 & 0.005 & 0.000 & 0.047 & 0.005 & 0.000 & 0.043 & 0.005 & 0.000 & 0.043 & 0.005 & 0.000 \\
\hline North East & 0.009 & 0.003 & 0.001 & 0.009 & 0.003 & 0.001 & 0.009 & 0.003 & 0.002 & 0.009 & 0.003 & 0.002 \\
\hline Centre & 0.018 & 0.003 & 0.000 & 0.018 & 0.003 & 0.000 & 0.019 & 0.003 & 0.000 & 0.019 & 0.003 & 0.000 \\
\hline South & 0.002 & 0.004 & 0.659 & 0.002 & 0.004 & 0.624 & 0.002 & 0.004 & 0.657 & 0.002 & 0.004 & 0.621 \\
\hline Year 2007 & -0.011 & 0.002 & 0.000 & -0.011 & 0.002 & 0.000 & -0.010 & 0.002 & 0.000 & -0.009 & 0.002 & 0.000 \\
\hline Sigma & 0.183 & 0.004 & & 0.183 & 0.004 & & & & & & & \\
\hline Sigma(u) & & & & & & & 0.12 & 0.003 & $* * *$ & 0.119 & 0.003 & $* * *$ \\
\hline Sigma(e) & & & & & & & 0.14 & 0.002 & $* * *$ & 0.14 & 0.002 & $* * *$ \\
\hline $\mathrm{Chi}^{2}$ & & & & & & & 486.21 & & & 486.21 & & \\
\hline Prob $>$ chi $^{2}$ & & & & & & & 0.000 & & & 0.000 & & \\
\hline $\mathrm{F}()$. & 13.39 & & 12.89 & & & & & & & & & \\
\hline Prob $>F$ & 0.000 & & 0.000 & & & & & & & & & \\
\hline Pseudo R ${ }^{2}$ & 0.433 & & 0.442 & & & & & & & & & \\
\hline No. of Obs & 6655 & & & & & & & & & & & \\
\hline
\end{tabular}

Estimated coefficients (selected variables)

\begin{tabular}{lcccccccccccc}
\hline Variable & Coef. & s.d. & p-val. & Coef. & s.d. & p-val. & Coef. & s.d. & p-val. & Coef. & s.d. & p-val. \\
\hline Volatility & 0.112 & 0.025 & 0.000 & 0.143 & 0.029 & 0.000 & 0.099 & 0.022 & 0.000 & 0.127 & 0.024 & 0.000 \\
Union & -0.023 & 0.006 & 0.000 & 0.014 & 0.013 & 0.258 & -0.020 & 0.006 & 0.001 & 0.016 & 0.013 & 0.222 \\
Union*volatility & & & & -0.098 & 0.032 & 0.002 & & & & -0.092 & 0.030 & 0.002 \\
\hline \hline
\end{tabular}

Notes: standard errors clustered by firms.

* In models 2 and 4 the ATE for union and for volatility are computed after accounting for the interaction term in (1). Controls include

10 sector dummies. Reference group: firms in the North-West of Italy employing 15-10 employees. 